\title{
STUDY OF SPLENIC NOTCHES: ITS EMBRYOLOGICAL ORIGIN AND
} CLINICAL SIGNIFICANCE

\author{
Divya Shanthi D'Sa ${ }^{1}$, Sangeetha V *2, Sundar G ${ }^{3}$. \\ ${ }^{1, * 2}$ Assistant Professor, Subbaiah Institute of Medical Sciences, Shimoga, Karnataka, India. \\ ${ }^{3}$ Assistant Professor, Government Vellore Medical College, Vellore, Tamil Nadu, India.
}

\section{ABSTRACT}

Introduction: In humans, spleen is one of the largest and single secondary lymphoid organs with high vascularity. The spleen develops from the mesoderm and during its development, different lobules are formed, which fuses with each other later on which is indicated in the form of the lobulations in adult spleen that can be seen on the superior as well as on the inferior borders.

Materials and methods: The study was done in the department of Anatomy, Subbaiah Institute of Medical Sciences, Shimoga in association with Government Vellore Medical College, Vellore. A total of 60 adult human cadaveric spleens were studied. Splenic notches and fissures were studied with regard to its different borders. The data obtained was tabulated, analysed statistically and compared with the previous studies.

Results: Out of the 60 spleens observed, 42 (70\%) spleen showed notches on the superior border, 6 (10\%) spleen showed notches on the inferior border. 12 (20\%) spleen did not show any notches on both superior and inferior border. The number of splenic notches on the superior border varied between 1 and 6 . But the majority of the spleens showed notches that varied between 1 and 3 on the superior border. Fissures along the superior border were observed in 3 specimens.

Conclusion: Splenomegaly is common in case of malaria, kalazar, typhoid, acute and chronic leukemias. In these common cases, the physician feels the notches of spleen on the superior border. It is essential for the surgeons and radiologists to become completely aware of anatomical variations that may help in accurate clinical diagnosis and treatment of the disease.

KEY WORDS: Lobulations, Notches, Spleen, Splenomegaly, Superior border.

Corresponding Author: Dr. Sangeetha V, Assistant Professor, Department of Anatomy, Subbaiah Institute of Medical Sciences, Purle Post, Holehonnur Road, Shimoga-577222, Karnataka, India. Mobile No: 9481831659 E-Mail: sanman17svg@gmail.com

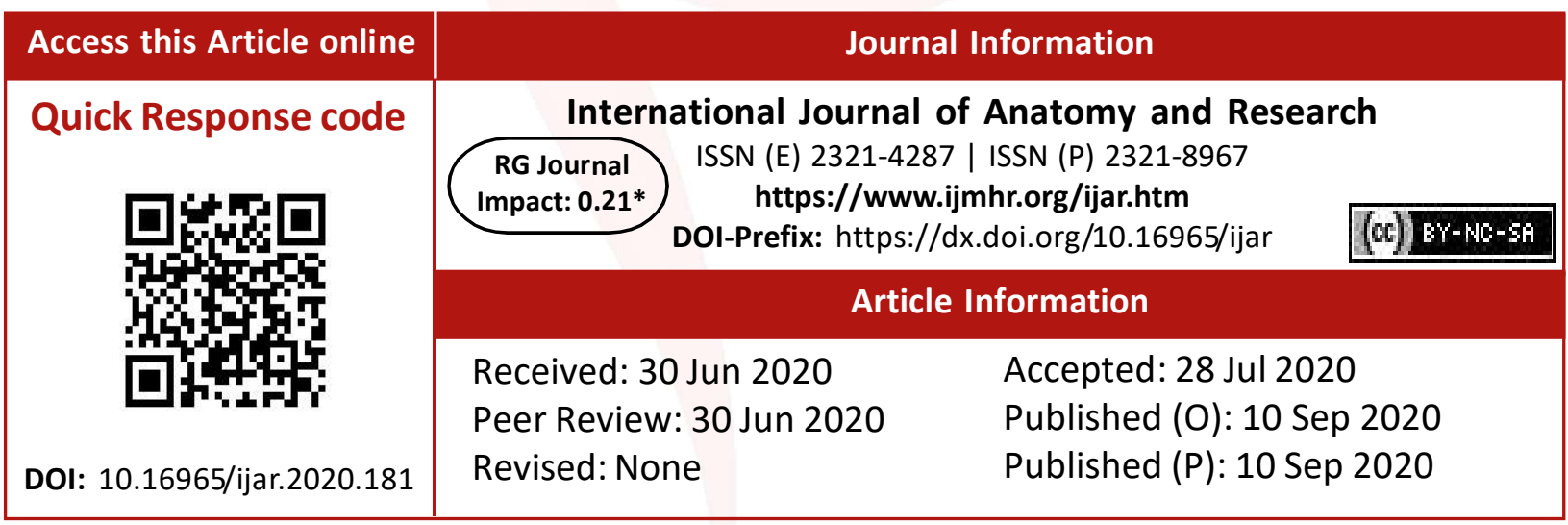

\section{INTRODUCTION}

Spleen is the largest and single secondary lymphoid organ in humans with high vascularity. Since it is related to both the circulatory and lymphoid system, spleen performs haematological as well as immunological function. In an average adult, the spleen is wedge shaped and measures $3-4 \mathrm{~cm}$ thick, $7 \mathrm{~cm}$ broad, $12 \mathrm{~cm}$ long, and $150 \mathrm{~g}$ in weight. Spleen has two surfaces, visceral and parietal and three borders, superior, inferior and intermediate. The superior border separates the gastric area from the diaphragmatic surface and the inferior border separates the renal area from the diaphragmatic surface [1-4].

The spleen develops from mesenchymal condensation in the dorsal mesogastrium during the sixth week of gestation. The mesenchymal cells 
between the leaflets of dorsal mesogastrium and the cells of the coelomic epithelium of the dorsal mesentery form the early spleen [2,5-14]. The proliferating cells invade the underlying angiogenetic mesenchyme, which becomes condensed and vascularized. The process occurs simultaneously in several adjoining areas which soon fuse to form a lobulated spleen. Lymphocytes migrate to the spleen late in the fetal life, from the central lymph organs. The earlier lobulated structure of the spleen disappears, but is indicated by the presence of notches on the superior border in the adult $[2,3,6,7,14]$. The embryological basis for the presence of notches on the superior margin is the improper fusion of the splenic nodules along this margin during development.

The number of notches varies from zero to six, but commonly, only one or two notches are seen. The superior border of the spleen possesses characteristic notch on its anterior part [2-4]. Normally spleen is not palpable, but if it is enlarged two or three times of its normal size then it is palpable. Usually abnormally enlarged spleen is identified by palpating the splenic notches. When spleen is enlarged, it enlarges towards the umbilicus and right iliac fossa.

\section{MATERIALS AND METHODS}

The study was done in the department of Anatomy, Subbaiah Institute of Medical Sciences, Shimoga in association with Government Vellore Medical College, Vellore. A total of 60 adult human cadaveric spleens were studied. Splenic notches and fissures were studied with regard to its different borders. The data obtained was tabulated, analysed statistically and compared with the previous studies.

\section{RESULTS}

Out of the 60 spleens observed, 42 (70\%) spleen showed notches on the superior border, $6(10 \%)$ spleen showed notches on the inferior border. $12(20 \%)$ spleen did not show any notches on both superior and inferior border. The number of splenic notches on the superior border varied between 1 and 6 (Fig:1). But the majority of the spleens showed notches that varied between 1 and 3 on the superior border. Fissures along the superior border were observed in 3 specimens. A deep fissure extending from the superior to inferior border was seen (Fig:2). Our observations are tabulated in table 1 . The study was compared with the previous studies and correlated.

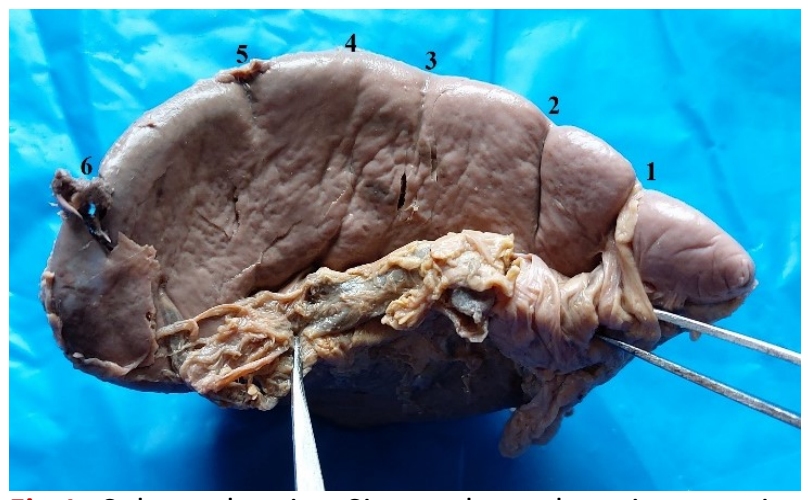

Fig.1: Spleen showing Six notches, along its superior border.

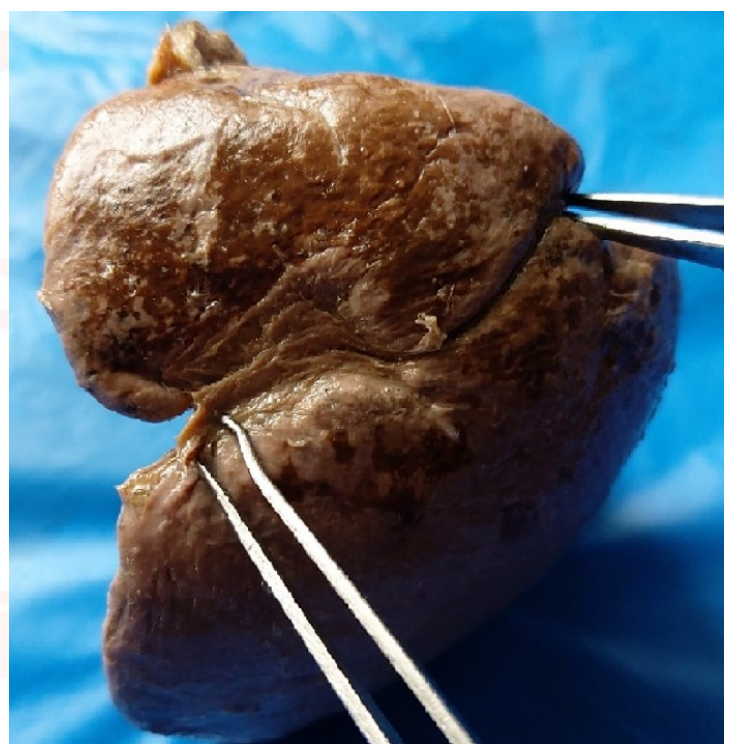

Fig.2: Deep fissure extending from superior to inferior border.

\section{DISCUSSION}

In the present study, out of the 60 spleens observed, 42 (70\%) spleen showed notches on the superior border, $6(10 \%)$ spleen showed notches on the inferior border. 12 (20\%) spleen did not show any notches on both superior and inferior border. The number of splenic notches on the superior border varied between 1 and 6 (Fig:1). Majority of the spleens showed notches that varied between 1 and 3 on the superior border. Fissures along the superior border were observed in 3 specimens. A deep fissure extending from the superior to inferior border was seen (Fig: 2). The study was compared and corelated with the previous studies as shown in Table 2 \& 3. 
Divya Shanthi D'Sa, Sangeetha V, Sundar G. STUDY OF SPLENIC NOTCHES: ITS EMBRYOLOGICAL ORIGIN AND CLINICAL SIGNIFICANCE.

Table 1: Present study.

\begin{tabular}{|cccccc|}
\hline No of specimens showing notches & Column1 & Column2 & No of notches & No of fissures \\
\hline Notches & No & $\%$ & - & - \\
\hline Total & 48 & 80 & - & - \\
\hline Superior border & 42 & 70 & $1-6$ & 3 \\
\hline Inferior border & 6 & 10 & 1 & - \\
\hline Absent & 12 & 20 & - & - \\
\hline
\end{tabular}

Table 2: Comparison of the present study with previous studies showing the number of notches present on different borders of the spleen.

\begin{tabular}{|c|c|c|c|c|c|c|c|}
\hline \multirow{2}{*}{ SI no } & \multirow{2}{*}{ Study } & \multirow{2}{*}{ Year } & \multirow{2}{*}{$\begin{array}{c}\text { No of } \\
\text { specimens }\end{array}$} & \multicolumn{3}{|c|}{ No of notches } & \multirow{2}{*}{ Fissures } \\
\hline & & & & $\begin{array}{c}\text { Superior } \\
\text { border }\end{array}$ & $\begin{array}{l}\text { Inferior } \\
\text { border }\end{array}$ & $\begin{array}{l}\text { Anterior } \\
\text { pole }\end{array}$ & \\
\hline 1. & Das et.al [7] & 2008 & - & $0-4$ & - & - & - \\
\hline 2. & Gandhi KR et.al [17] & 2013 & 1 & 6 & - & 1 & Present (1) \\
\hline 3. & Girish V. Patil et.al [18] & 2014 & 60 & $1-4$ & - & - & - \\
\hline 4. & Thanya I. Pathirana et.al [21] & 2016 & 1 & 8 & 1 & - & - \\
\hline 5. & Bhumica Dang et al [22] & 2018 & 60 & $1-5$ & 1 & - & Present (4) \\
\hline 6. & Shivakumar AH et.al [23] & 2019 & 50 & $1-6$ & $1-4$ & - & - \\
\hline 7. & Present study & 2020 & 60 & $0-6$ & 1 & - & Present (3) \\
\hline
\end{tabular}

Table 3: Comparison of the present study with previous studies showing the number of notches present on different borders of the spleen.

\begin{tabular}{|c|c|c|c|c|c|c|c|c|c|}
\hline \multirow{3}{*}{ SI no } & \multirow{3}{*}{ Study } & \multirow{3}{*}{ Year } & \multirow{3}{*}{$\begin{array}{c}\text { No of } \\
\text { specimens }\end{array}$} & \multicolumn{6}{|c|}{ No of notches } \\
\hline & & & & \multicolumn{2}{|c|}{ Superior border } & \multicolumn{2}{|c|}{ Inferior border } & \multicolumn{2}{|c|}{ Absent notches } \\
\hline & & & & No & $\%$ & No & $\%$ & No & $\%$ \\
\hline 1 & Girish V. Patil et.al [18] & 2014 & 60 & 57 & 95 & 2 & 3.33 & 1 & 1.67 \\
\hline 2 & Hussein et.al [19] & 2013 & 32 & 3 & 9.3 & 4 & 12.5 & - & - \\
\hline 3 & Soyluolu AÝ et al [9] & 1996 & - & - & 70 & - & - & - & - \\
\hline 4 & Skandalakis PN et al [3] & 1993 & - & - & 78.6 & - & -- & - & - \\
\hline 5 & Ungor B et al [10] & 2007 & - & - & 95 & - & - & - & - \\
\hline 6 & Parsons, F.G [6] & 1901 & - & - & - & - & 8 & - & - \\
\hline 7 & Das et.al [7] & 2008 & - & - & 98 & - & 2 & - & - \\
\hline 8 & Nayak B S et.al [20] & 2011 & 50 & - & 50 & - & - & 25 & 50 \\
\hline 9 & Bhumica Dang et al [22] & 2018 & 60 & 51 & 85 & 5 & 8.33 & 9 & - \\
\hline 10 & Shivakumar AH et.al [23] & 2019 & 50 & - & - & - & - & - & - \\
\hline 11 & Present study & 2020 & 60 & 42 & 70 & 6 & 10 & 12 & 20 \\
\hline
\end{tabular}

Morphologically, the notches along the borders of spleen are variable in different animals. The spleen in carnivores is large with notch on all the borders whereas spleen is less notched in anthropoids [6]. Ox, goat, sheep, and horse have been found to display no notches whereas cat, dog, lion, wild dog, fox, ordinary seal have notches on all the borders [3-6]. Gayer et al. in their computed tomographic study on congenital anomalies of spleen noted that occasionally the notches or clefts on the superior border of the adult spleen were sharp and extended deep up to $2-3 \mathrm{~cm}$ [11]. The fissure on the diaphragmatic and visceral surface in one of our specimens may mimic an injury \& erroneously interpreted as a laceration in abdominal trauma patients during radiological investigation $[6,8]$. Spleen is a very important organ because of its function in relation to immunological and cytological activity especially with regard to its RBC storage and blood filtration potential [12]. Splenomegaly is common in case of malaria, kalazar, typhoid, acute and chronic leukemias. An enlarged spleen can be clinically detected in the left hypochondriac region of the abdomen through palpation. The notch on its anterior border aids in identifying the spleen and differentiating it from other abdominal organs $[4,15]$. If splenomegaly occurs in unnotched spleens, surgeons may misdiagnose it as renal swelling on left coastal margin. In the case of tumour of left kidney, the kidney is identified by its rounded border whereas the sharp anterior edge of the spleen is often notched $[4,8]$.

Hence, an accurate knowledge about the morphological variations of spleen is becomes 
obligatory. Furthermore, the spleen with many notches along its surface is categorized as a distributed type with a large hilum, in which the arterial branches are small and numerous $[3,7,13]$. This knowledge is of utmost importance in the management of haemorrhage in case of splenic rupture and during partial splenectomy where all these branches need to be carefully ligated.

Although traditional anatomical literature has invariably reported that the spleen has only one or two main notches, some authors have maintained that the number of notches may vary from one to six $[15,16]$. More recently Gandhi et al (2013) described a case where one spleen had seven notches and Thanya I. Pathirana et.al (2016) reported 9 notches.

\section{CONCLUSION}

The splenic notch, along the superior border of the spleen, is the most reliable feature used by the physicians in everyday clinical practice to palpate the enlarged spleen and distinguish it from adjoining organs. Variation in the number and location of notches may interfere in the manual and radiological identification of spleen.

In this era of imaging and minimally-invasive approaches, it is imperative on the part of both the radiologists and operating surgeons to have a thorough knowledge of the anatomy and the commonly-occurring variations in this organ. Accurate knowledge of anatomical variations is of vital importance for clinicians, surgeons \& radiologists to improve diagnostic and therapeutic outcomes. Nevertheless, this knowledge is very important for anatomists during their routine classroom dissections.

\section{Conflicts of Interests: None}

\section{REFERENCES}

[1]. Kato T, Tzakis AG, Selvaggi G, Gaynor JJ, Takahashi H, Mathew J, et al. Transplantation of the Spleen Effect of Splenic Allograft in Human Multivisceral Transplantation. Ann Surg 2007; 246:436-46. https:// doi.org/10.1097/SLA.0b013e3181485124 PMid:17717447

[2]. Borley N. Spleen in Standring S Gray's Anatomy. 40 thed. London: Churchill Livingstone Elsevier; 2008. p. 1191-4.

[3]. Skandalakes EJ. Surgical Anatomy [The Embryological and Anatomical Basis of Modern Surgery] In Spleen, Paschalides Medical Publications. Vol. 2. Athens, Greece. 2004. p. 1231-77.
[4]. Coetzee T. Clinical anatomy and physiology of the spleen. S Afr Med J 1982; 61:737-46.

[5]. Sant S. Embryology for medical students. New Delhi: Jaypee brothers' medical publishers (p) Itd., 2002; 203-04.

[6]. Parsans FJ, Notches and fissures of the spleen. AnatPhysiol 1901; 35:416-27.

[7]. Das S, Abd Latiff A, Suhaimi FH, Ghazalli H, Othman F. Anomalous splenic notches: A cadaveric study with clinical implications. Bratisl Lek Listy 2008; 109:513-6.

[8]. Nayak BS, Somayaji and SN, Soumya KV. A Study on the Variations of Size, Shape and External Features of the Spleen in South Indian Population. Int J Morphol 2011; 29:675-7. https://doi.org/10.4067/ S0717-95022011000300001

[9]. Soyluolu AÝ, Tanyeli E, Marur T, Ertem AD, Özku K, Akkýn, SM. Splenic artery and the Relation between the tail of pancreas and spleen in a surgical anatomical view. Karadeniz TýpDergisi 1996; 9:103- 107.

[10]. Ungor B, Malas MA, Sulak O, Albay S. Development of spleen during the fetal period. SurgRadiol Anat. 2007 Oct; 29(7):543-50. https://doi.org/10.1007/ s00276-007-0240-2 PMid:17671754

[11]. Gayer G, Zissin R, Apter S, Atar E, Portnoy O, Itzchak $\mathrm{Y}$. CT findings in congenital anomalies of the spleen. Br J Radiol2001; 74:767-72. https://doi.org/ 10.1259/bjr.74.884.740767 PMid:11511506

[12]. Williams, NS. Bulstrode, CJK Ronan O'Connell, P. Bailey \& Love's. Short Practice of Surgery. Hodder Arnold. London., 25th ed .2008; 1101-1110.

[13]. Redmond HP, Redmond JM, Rooney BP, Duignan JP, BouchierHayes DJ. Surgical anatomy of the human spleen. Br J Surg1989; 76:198-201. https:// doi.org/10.1002/bjs.1800760230 PMid:2702458

[14]. Larsen WJ. Development of the gastrointestinal tract. In: Larsen WJ, editor. Human embryology. 4th ed. New York: Churchill Livingstone; 2009. p. 454.

[15]. Standring, S. Gray's Anatomy. The Anatomical Basis of Clinical Practice. New York, Elsevier Churchill Livingstone, 2005. Pp.1239-44.

[16]. Michels N.A. The variational anatomy of the spleen and splenic artery. Am. J. Anat. 1942; 70: 21-72. https://doi.org/10.1002/aja.1000700103

[17]. Gandhi KR, Chavan SK, Oommen SA. Spleen with multiple notches: $A$ rare anatomical variant with its clinical significance. Int J Stud Res 2013; 3:24-5. https://doi.org/10.4103/2230-7095.113829

[18]. Girish V. Patil et.al. Study of splenic notches in a human cadaver. International Journal of Recent Advances in Multidisciplinary Research Aug, 2014;01(02):001-003. https://doi.org/10.1055/s0038-1671977

[19]. Hussein et.al. Anatomical Variations of Spleen in North Indian Population and its Clinical Significance. Innovative Journal of Medical and Health Science2013;3(4):190-192.

[20]. Nayak, B. S.; Somayaji, S. N. \& Soumya, K. V. A Study on the variations of size, shape and external features of the spleen in south Indian population. Int. J. Morphol., 2011;29(3):675-677. https://doi.org/ $10.4067 /$ S0717-95022011000300001 
[21]. Thanya I. Pathirana et.al. A rare anomaly of the human spleen with nine notches associated with multiple accessory spleens. A case study, hypothesis on origin and review of clinical significance. Italian Journal of Anatomy and Embryology. 2016;121(2):188-197.

[22]. Bhumica Dang, Vivek Singh Malik, Sanjay Gupta, Sudha Chhabra. Variations in splenic notches and fissures: study with clinical importance. Int J Anat Res 2018;6(1.1):4803-4805. https://doi.org/ 10.16965/ijar.2017.468
[23]. Shivakumar AH, Sumana R. Multiple notches on the spleen, an important differential diagnosis for rupture spleen: An anatomical approach. Indian J AnatSurg Head Neck Brain 2019;5(2):48-50. https://doi.org/10.18231/j.ijashnb.2019.012

How to cite this article:

Divya Shanthi D'Sa, Sangeetha V, Sundar G. STUDY OF SPLENIC NOTCHES: ITS EMBRYOLOGICAL ORIGIN ANDCLINICAL SIGNIFICANCE. Int J Anat Res 2020;8(3.3):7707-7011. DOI: 10.16965/ijar.2020.181 